\title{
PENGARUH LOYALITAS, KEMAMPUAN KERJA, KEMATANGAN PEGAWAI DAN DISIPLIN KERJA TERHADAP KINERJA PEGAWAI PADA KANTOR PELAYANAN PAJAK PRATAMA MEDAN TIMUR
}

\author{
Harryadinata \\ Universitas Islam Sumatera Utara \\ Harry.adinata@gmail.com
}

\begin{abstract}
The problem in this research is: How does the influence of loyalty on employee performance at the East Medan Pratama Tax Service Office. How does the effect of work ability on employee performance, How does the influence of employee maturity on employee performance, How does the influence of work discipline on employee performance, How does the influence of loyalty, work ability, employee maturity and work discipline on employee performance at the East Medan Pratama Tax Service Office. The hypothesis proposed is: Loyalty has a positive and significant effect on employee performance, work ability has a positive and significant effect on employee performance, Maturity of employees has a positive and significant effect on employee performance, Work discipline has a positive and significant effect on employee performance, Loyalty, work ability, maturity employees and work discipline have a positive and significant effect on employee performance at the East Medan Tax Service Office. The study was conducted at the East Medan Pratama Tax Office. Jalan Sukamulia No. 17-A, Medan-2015, and the study sample of 86 people.
\end{abstract}

Keyworld : loyalty, work ability, employee maturity, work discpline and employee performance

ABSTRAK : Masalah dalam peneltian ini adalah: Bagaimana pengaruh loyalitas terhadap kinerja pegawai pada Kantor Pelayanan Pajak Pratama Medan Timur. Bagaimana pengaruh kemampuan kerja terhadap kinerja pegawai, Bagaimana pengaruh kematangan pegawai terhadap kinerja pegawai, Bagaimana pengaruh disiplin kerja terhadap kinerja pegawai, Bagaimana pengaruh loyalitas, kemampuan kerja, kematangan pegawai dan disiplin kerja terhadap kinerja pegawai pada Kantor Pelayanan Pajak Pratama Medan Timur. Hipotesis yang diajukan adalah : Loyalitas berpengaruh positif dan signifikan terhadap kinerja pegawai, Kemampuan kerja berpengaruh positif dan signifikan terhadap kinerja pegawai, Kematangan pegawai berpengaruh positif dan signifikan terhadap kinerja pegawai, Disiplin kerja berpengaruh positif dan signifikan terhadap kinerja pegawai, Loyalitas, kemampuan kerja, kematangan pegawai dan disiplin kerja berpengaruh positif dan signifikan terhadap kinerja pegawai pada Kantor Pelayanan Pajak Medan Timur. Penelitian dilakukan di Kantor Pelayanan Pajak Pratama Medan Timur. Jalan Sukamulia No. 17-A, Medan-2015, dan sampel penelitian sebanyak 86 orang.

Keyworld : loyalitas, kemampuan kerja, kematangan pegawai, disiplin kerja dan Kinerja Pegawai

\section{Pendahuluan}

Keberhasilan pelaksanaan kegiatan di Kantor Pelayanan Pajak Pratama Medan Timur dalam segala aspek merupakan bagian yang tidak terpisahkan dari keseluruhan proses pelaksanaan pembangunan di wilayah Kota Medan pada khususnya dan pembangunan nasional pada umumnya yang diarahkan untuk menuju masyarakat yang adil, makmur, sejahtera, mandiri dan bermartabat. Keberhasilan Pemerintah Kota Medan tidak akan mungkin terwujud tanpa didukung oleh aparatur negara daerah yang memiliki kapasitas dan kapabilitas dalam bidang tugasnya masing- masing, transparan, profesional dan akuntanbel, yang telah ditetapkan dengan memperhitungkan antara perencanaan dengan realisasi indikator keluaran (out put), indikator manfaat (out come) dan indikator hasil (benefit). Variabel pertama yang mempengaruhi kinerja pegawai Kantor Pelayanan Pajak Pratama Medan Timur adalah loyalitas.

Penelitian terdahulu yang menyatakan loyalitas berpengaruh terhadap kinerja adalah penelitian dari Aldrianto (2016) dan Murty (2014). Menurut Danim (2003:24), loyalitas adalah ukuran hasil yang diperoleh antara suatu mekanisme yang telah ditetapkan 
dengan tenaga yang dihasilkan. Variabel kedua yang diduga mempengaruhi kinerja pegawai Kantor Pelayanan Pajak Pratama Medan Timur adalah kemampuan kerja. Penelitian terdahulu yang menyatakan kemempauan berpengaruh terhadap kinerja adalah penelitian dari Ageng (2016), Saka (2014) dan Septiani at.al (2015).

Menurut Robbins (2001:46) kemampuan kerja adalah kemampuan mental yang diperlukan untuk menjalankan kegiatan mental. Variabel ketiga yang mempengaruhi kinerja pegawai Kantor Pelayanan Pajak Pratama Medan Timur adalah kematangan pegawai. Menurut Suryana (2009:88) kematangan adalah kemampuan individu untuk dapat mengontrol dan mengendalikan diri terhadap pekerjaan yang menjadi tanggung jawabnya. Kematangan mempunyai ciri-ciri penerimaan diri, baik individu yang memiliki kematangan akan dapat menerima kondisi fisik maupun psikisnya, baik secara pribadi maupun secara sosial, dan kemampuan dalam mengontrol dorongan yang muncul dalam diri individu untuk melakukan sesuatu yang bertentangan dengan nilai-nilai yang berlaku akan dapat dikendalikan dan di organisasikan ke arah yang baik

Adapun Tujuan Penelitian ini adalah :

1. Untuk mengetahui dan menganalisis pengaruh loyalitas terhadap kinerja pegawai pada Kantor Pelayanan Pajak Pratama Medan Timur.

2. Untuk mengetahui dan menganalisis pengaruh kemampuan kerja terhadap kinerja pegawai pada Kantor Pelayanan Pajak Pratama Medan Timur.

3. Untuk mengetahui dan menganalisis pengaruh kematangan pegawai terhadap kinerja pegawai pada Kantor Pelayanan Pajak Pratama Medan Timur.

4. Untuk mengetahui dan menganalisis pengaruh disiplin kerja terhadap kinerja pegawai pada Kantor Pelayanan Pajak Pratama Medan Timur.

Untuk mengetahui dan menganalisis pengaruh loyalitas, kemampuan kerja, kematangan pegawai dan disiplin kerja terhadap kinerja pegawai pada Kantor Pelayanan Pajak Pratama Medan Timur.

\section{Penelitian Terdahulu}

Tabel 1

Penelitian Terdahulu

\begin{tabular}{|c|c|c|c|c|}
\hline No & Penelitian & Tahun & Judul Penelitian & Hasil Penelitian \\
\hline 1. & $\begin{array}{l}\text { Saeed, S., dan } \\
\text { Syah, F.M }\end{array}$ & 2016 & $\begin{array}{l}\text { Impact of Performance } \\
\text { Appraisal on Employee } \\
\text { Motivation in Islamic } \\
\text { Banking }\end{array}$ & $\begin{array}{l}\text { Motivasi berpengaruh } \\
\text { positif terhadap kinerja }\end{array}$ \\
\hline 2. & $\begin{array}{l}\text { Ali, } \quad \text { A.Y.S., } \\
\text { Dahie, } \\
\text { dan Ali, }\end{array}$ & 2016 & $\begin{array}{l}\text { Teacher Motivation and } \\
\text { School Performance, the } \\
\text { Mediating Effect of Job } \\
\text { Satisfaction: Survey from } \\
\text { Secondary Schools in } \\
\text { Mogadishu }\end{array}$ & $\begin{array}{lr}\text { Motivasi } & \text { guru } \\
\text { berpengaruh } & \text { terhadap } \\
\text { kinerja melalui } & \text { kepuasan } \\
\text { kerja } & \end{array}$ \\
\hline 3. & $\begin{array}{l}\text { Nurchayani, } \\
\text { N.M dan } \\
\text { Adnyani, } \\
\text { I.G.A.D }\end{array}$ & 2016 & $\begin{array}{l}\text { Pengaruh Kompensasi } \\
\text { dan Motivasi terhadap } \\
\text { Kinerja karyawan dengan } \\
\text { kepuasan Kerja sebagai } \\
\text { Variabel Intervening }\end{array}$ & $\begin{array}{l}\text { Kompensasi dan motivasi } \\
\text { berpengaruh } \\
\text { kinerja karyawan melalui } \\
\text { kepuasan kerja }\end{array}$ \\
\hline 4. & $\begin{array}{l}\text { Ageng } \\
\text { Prawatya }\end{array}$ & 2015 & $\begin{array}{l}\text { Pengaruh Motivasi, } \\
\text { Kemampuan dan disiplin } \\
\text { kerja terhadap kinerja } \\
\text { Karyawan Pada PT. PLN } \\
\text { Cabang Weleri }\end{array}$ & \begin{tabular}{llr}
\multicolumn{2}{l}{ Motivasi, } & \multicolumn{2}{c}{ Kemampuan } \\
dan disiplin & kerja \\
berpengaruh & terhadap \\
kinerja & karyawan & baik \\
secara & partial & dan \\
simultan & &
\end{tabular} \\
\hline 5. & $\begin{array}{l}\text { Aldrianto } \\
\text { Muhammad }\end{array}$ & 2016 & $\begin{array}{l}\text { Pengaruh disiplin dan } \\
\text { loyalitas terhadap kinerja } \\
\text { karyawan pada PT. }\end{array}$ & $\begin{array}{l}\text { Disiplin dan loyalitas } \\
\text { berpengaruh terhadap } \\
\text { kinerja karyawan baik }\end{array}$ \\
\hline
\end{tabular}




\begin{tabular}{|c|l|l|l|l|}
\hline No & \multicolumn{1}{|c|}{ Penelitian } & Tahun & \multicolumn{1}{|c|}{ Judul Penelitian } & \multicolumn{1}{|c|}{ Hasil Penelitian } \\
\hline & & & Kospermindo di Makasar & partial maupun simultan \\
\hline 6. & Septiani & 2015 & $\begin{array}{l}\text { Pengaruh kemampuan dan } \\
\text { kematangan terhadap }\end{array}$ & Kemampuan kematangan berpengaruh \\
& Agustina & & keman \\
& Shafiah, & & kinerja Pegawai Kantor & terhadap kinerja baik \\
& Siswidiyanto, & & Pelayanan Terpadu & secara partial maupun \\
& Wima Yudo & & Lumajang & simultan \\
& Prasetyo & & & \\
\hline
\end{tabular}

\subsection{Kerangka Berpikir}

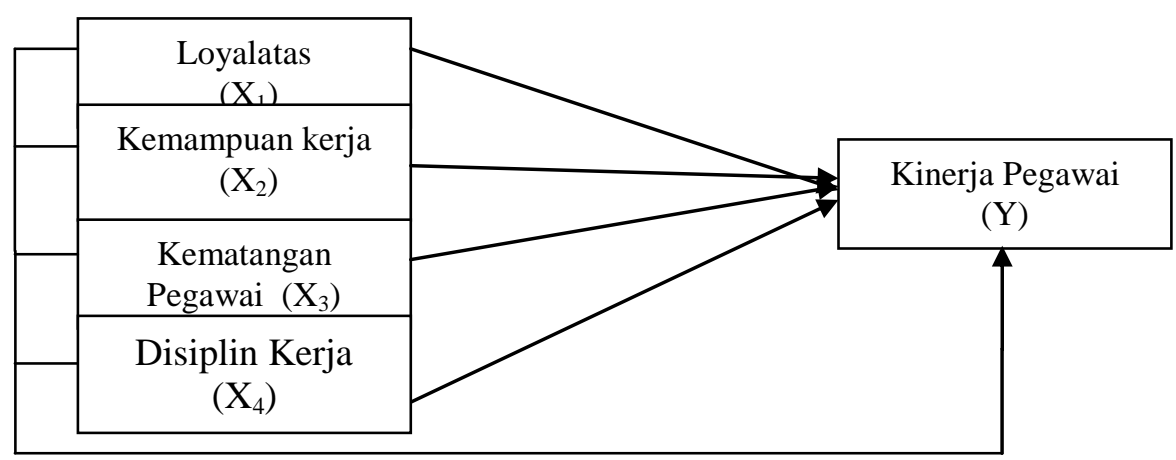

Gambar 1 Kerangka Konseptual

\subsection{Hipotesis}

Hipotesis adalah jawaban sementara terhadap masalah penelitian, yang kebenarannya harus diuji secara empiris. Hipotesis dalam penelitian ini adalah :

1. Loyalitas berpengaruh positif dan signifikan terhadap kinerja pegawai pada Kantor Pelayanan Pajak Medan Timur.

2. Kemampuan kerja berpengaruh positif dan signifikan terhadap kinerja pegawai pada Kantor Pelayanan Pajak Medan Timur.

3. Kematangan pegawai berpengaruh positif dan signifikan terhadap kinerja pegawai pada Kantor Pelayanan Pajak Medan Timur.

4. Disiplin kerja berpengaruh positif dan signifikan terhadap kinerja pegawai pada Kantor Pelayanan Pajak Medan Timur.

5. Loyalitas, kemampuan kerja, kematangan pegawai dan disiplin kerja berpengaruh positif dan signifikan terhadap kinerja pegawai pada Kantor Pelayanan Pajak Medan Timur.

\section{Metode Penelitian}

\subsection{Lokasi Penelitian}

Lokasi penelitian dilakukan di Kantor Pelayanan Pajak Pratama Medan Timur. Jalan Sukamulia No. 17-A, Medan-20151.

\subsection{Populasi}

Populasi dalam penelitian ini adalah pegawai Kantor Pelayanan Pajak Pratama Medan Timur yang berjumlah 110 orang dimana peneliti tidak dijadikan populasi, dengan rincian sebagai berikut.

\subsection{Sampel}

Untukmenentukanjumlahsampel, digunakanpendapatSlovindalam Sekaran dan Bougie (2010:112) denganmenggunakan formula sebagaiberikut :

$$
n=\frac{N}{1+N \mathrm{e}^{2}}
$$

Keterangan :

$$
\begin{aligned}
& \mathrm{n} \quad \text { : JumlahSampel } \\
& \mathrm{N} \quad \text { : JumlahPopulasi } \\
& e \quad: \text { Kesalahan yang ditolerir } \\
& \text { dalam penarikan sampel yaitu } 0,05 .
\end{aligned}
$$

Berdasarkan formula diatas, selanjutnya dapat dihitung jumlah sampel dalam penelitian ini sebagai berikut :

$$
\begin{aligned}
& \mathrm{n}=\frac{110}{1+110(0,05)^{2}} \\
& \mathrm{n}=\frac{110}{1.275} \\
& \mathrm{n}=86.27=86 \text { orang }
\end{aligned}
$$

Setelah perhitungan di atas, penetapan jumlah sampel dalam penelitian ini 
menggunakan metode stratified random sampling yaitu penarikan sampel berdasarkan pada strata populasi pada setiap bagian, sehingga sampel dalam penelitian ini berjumlah 86 orang pegawai, dengan rincian sebagai berikut :

Tabel 2

Kerangka sampel berdasarkan jabatan

\begin{tabular}{|l|l|l|}
\hline No & Keterangan/Jabatan & Jumlah \\
\hline
\end{tabular}

\begin{tabular}{l|l|c|}
\hline & & (Orang) \\
\hline 1 & KepalaSeksi & 7 \\
\hline 2 & Account Representative & 38 \\
\hline 3 & Fungsional & 11 \\
\hline 4 & Pelaksana & 30 \\
\hline \multicolumn{2}{|c|}{ Jumlah } & 86 \\
\hline
\end{tabular}

\subsection{Definisi Operasional Variabel}

Tabel 3

Definisi operasional variabel

\begin{tabular}{|c|c|c|c|c|}
\hline No & DefenisiVariabel & $\begin{array}{c}\text { Jenis } \\
\text { Variabel }\end{array}$ & Indikator & $\begin{array}{c}\text { Skala } \\
\text { Pengukuran }\end{array}$ \\
\hline 1. & $\begin{array}{l}\text { Loyalitas adalah ukuran hasil } \\
\text { yang diperoleh antara suatu } \\
\text { mekanisme yang telah } \\
\text { ditetapkan dengan tenaga } \\
\text { yang dihasilkan. } \\
\text { Anoraga }(2008: 24) \text {, }\end{array}$ & $\begin{array}{c}\text { Variabel } \\
\text { bebas }\end{array}$ & $\begin{array}{l}\text { 1) Taat pada peraturan } \\
\text { 2) Tanggungjawab pada } \\
\text { organisasi } \\
\text { 3) Kemamuan untuk } \\
\text { kerjasama } \\
\text { 4) Rasa memiliki } \\
\text { 5) Hubungan antar pribadi } \\
\text { 6) Kesukaan pada pekerjaan }\end{array}$ & $\begin{array}{l}\text { Skala } \\
\text { Ordinal }\end{array}$ \\
\hline 2. & $\begin{array}{l}\text { Kemampuan kerja adalah } \\
\text { kemampuan mental yang } \\
\text { diperlukan untuk menjalankan } \\
\text { kegiatan mental. } \\
\text { Robbins (2001:46) }\end{array}$ & $\begin{array}{c}\text { Variabel } \\
\text { bebas }\end{array}$ & $\begin{array}{l}\text { 1) Pembawaan } \\
\text { 2) Kematangan } \\
\text { 3) Pembentukan } \\
\text { 4) Minat } \\
\text { 5) Kebebasan }\end{array}$ & $\begin{array}{l}\text { Skala } \\
\text { Ordinal }\end{array}$ \\
\hline 3. & $\begin{array}{l}\text { Kematangan mengacu pada } \\
\text { kapasitas seseorang untuk } \\
\text { bereaksi dalam berbagai situasi } \\
\text { kehidupan dengan cara-cara } \\
\text { yang lebih bermanfaat dan } \\
\text { bukan dengan cara- } \\
\text { carabereaksi. } \\
\text { Sutrisno (2014:110) }\end{array}$ & $\begin{array}{l}\text { Variabel } \\
\text { terikat }\end{array}$ & $\begin{array}{ll}\text { 1) } & \text { Fisik } \\
\text { 2) } & \text { Pola control } \\
\text { 3) } & \text { Itelegensi } \\
\text { 4) } & \text { Jeniskelamin } \\
\text { 5) } & \text { Usia }\end{array}$ & $\begin{array}{l}\text { Skala } \\
\text { Ordinal }\end{array}$ \\
\hline 4. & $\begin{array}{l}\text { Disiplin adalah sikap dari } \\
\text { seseorang/kelompok orang } \\
\text { yang senantiasa berkehendak } \\
\text { untuk mengikuti/mematuhi } \\
\text { segala aturan/keputusan yang } \\
\text { ditetapkan. } \\
\text { Sudjana (2004: 135) }\end{array}$ & $\begin{array}{c}\text { Variabel } \\
\text { bebas }\end{array}$ & $\begin{array}{l}\text { 1) Ketepatan waktu } \\
\text { 2) Menggunakan peralatan } \\
\text { dengan baik } \\
\text { 3) Tanggung jawab } \\
\text { 4) Ketaatan pada peraturan }\end{array}$ & $\begin{array}{l}\text { Skala } \\
\text { Ordinal }\end{array}$ \\
\hline 5. & $\begin{array}{l}\text { Kinerja berarti prestasi kerja, } \\
\text { pelaksanaan kerja, pencapaian } \\
\text { kerja, hasil kerja.. } \\
\text { Sedarmayanti, }(2001: 50)\end{array}$ & $\begin{array}{c}\text { Variabel } \\
\text { terikat }\end{array}$ & $\begin{array}{l}\text { 1) Kualitas kerja } \\
\text { 2) Kuantitas kerja } \\
\text { 3) Konsistensi kerja } \\
\text { 4) Sikapkerja }\end{array}$ & $\begin{array}{l}\text { Skala } \\
\text { Ordinal }\end{array}$ \\
\hline
\end{tabular}

Sumber: Sedarmayanti, (2001), Sudjana (2004), Sutrisno (2014), Robbins (2001), Anoraga (2008

\subsection{Variabel Penelitian}

Terdapat dua variabel dalam penelitian ini, variabel-variabel tersebut adalah :

a. Variabel Terikat (Dependent variable) merupakan variabel yangdipengaruhi atau yang menjadi akibat, karena adanya variabel bebas. Pada penelitian ini yang menjadi variabel terikat yaitu kinerja (Y).

b. Variabel Bebas (Independent variable) merupakan variabel yangmempengaruhi atau yang menjadi sebab perubahannya atau timbulnyavariabel terikat. Pada penelitian ini 
yang menjadi variabel bebas adalah loyalitas $\left(\mathrm{X}_{1}\right)$, kemampuan kerja $\left(\mathrm{X}_{2}\right)$, kematangan pegawai $\left(\mathrm{X}_{3}\right)$, disiplin kerja $\left(\mathrm{X}_{4}\right)$

\subsection{Teknik Pengumpulan Data}

Teknik pengumpulan data dilakukan dengan pengumpulan data primer yaitu data yang dikumpulkan dari sumber-sumber asli untuk tujuan tertentu, atau data yang diperoleh dengan survei lapangan yang menggunakan metode pengumpulan data ordinal, yaitu :

a. Wawancara

Peneliti melakukan wawancara langsung dan tidak langsung dengan pegawai Kantor Pelayanan Pajak Pratama Medan Timur yang dapat memberikan informasi yang berhubungan dengan objek penelitian agar diperoleh data yang diinginkan.

b. Kuesioner / Angket Penelitian
Dengan memberikan
daftar pertanyaan/angket penelitian sesuai dengan data yang diinginkan kepada para responden yang berjumlah 86 orang
Dalam penelitian ini urutan pemberian skor menggunakan skala likert yang digunakan dalam penelitian ini adalah sebagai berikut : Sangat Setuju $=$ Skor 5
Setuju
$=$ Skor 4
Kurang setuju
$=$ Skor 3
Tidak Setuju
$=$ Skor 2
Sangat Tidak Setuju $=$ Skor 1

Dalam penelitian ini untuk menguji hipotesis penelitian menggunakan analisis regresi linier berganda yaitu melihat pengaruh bebas terhadap variabel terikat. Persyaratan dalam analisis regresi adalah uji asumsi klasik. Pengujian asumsi klasik diperlukan untuk mengetahui apakah hasil estimasi regresi yang dilakukan, benar-benar bebas dari adanya gejala heteroskedastisitas, gejala multikolinearitas, gejala autokorelasi dan gejala normalitas, dengan persamaan :

$$
\mathrm{Y}=\mathrm{a}+\mathrm{b} 1 \mathrm{X} 1+\mathrm{b} 2 \mathrm{X} 2+\mathrm{b} 3 \mathrm{X} 3+\mathrm{b} 4 \mathrm{X} 4+€
$$

Dimana :

\begin{tabular}{|c|c|}
\hline Y1 & $=$ Kinerja pegawai \\
\hline $\mathrm{a}$ & $=$ Konstanta \\
\hline $\mathrm{X} 1$ & $=$ Loyalitas \\
\hline $\mathrm{X} 2$ & $=$ Kemampuan kerja \\
\hline X3 & $=$ Kematangan pegawai \\
\hline X3 & $=$ Disiplin kerja \\
\hline b1,b2,b3, & $=$ Koefisien regresi \\
\hline$€$ & $=$ Standard error \\
\hline
\end{tabular}

\subsection{Hasil Dan Pembahasan}

Tabel 4

Koefisien Regresi

\begin{tabular}{|c|c|c|c|c|c|c|}
\hline \multirow{2}{*}{\multicolumn{2}{|c|}{ Model }} & \multicolumn{2}{|c|}{$\begin{array}{l}\text { Unstandardized } \\
\text { Coefficients }\end{array}$} & \multirow{2}{*}{$\begin{array}{l}\text { Standardize } \\
\mathrm{d} \\
\text { Coefficients } \\
\text { Beta }\end{array}$} & \multirow[t]{2}{*}{$\mathrm{t}$} & \multirow[t]{2}{*}{ Sig. } \\
\hline & & B & Std. Error & & & \\
\hline \multirow{5}{*}{1} & (Constant) & 14.357 & 1.777 & & 8.081 & .000 \\
\hline & Loyalitas & .099 & .044 & .190 & 2.257 & .027 \\
\hline & Kemampuan kerja & .090 & .053 & .148 & 1.709 & .091 \\
\hline & Kematangan pegawai & .303 & .082 & .396 & 3.720 & .000 \\
\hline & Disiplin kerja & .179 & .100 & .223 & 1.782 & .079 \\
\hline
\end{tabular}

Sumber : Hasil Pengolahan Data, 2019

Berdasarkan Tabel 5.17 diperoleh koefisien regresi variabel Loyalitas 0,099, Kemampuan kerja $=0,090$, kematangan pegawai 0,303 , disiplin kerja 0,179 dengan konstanta 14,357, maka dapat dituliskan persamaan regresi sebagai berikut.

$$
\mathrm{Y}=14,357+0,099 \mathrm{X}_{1}+0,090 \mathrm{X}_{2}+
$$
$0,303 \mathrm{X}_{3}+0,179 \mathrm{X}_{4}$

Persamaan di atas memberi gambaran bahwa perubahan rata-rata variabel Kinerja pegawai (Y) tergantung dari perubahan variabel Loyalitas $\left(\mathrm{X}_{1}\right), \quad$ Kemampuan kerja
$\left(\mathrm{X}_{2}\right)$.kematangan pegawai $\left(\mathrm{X}_{3}\right)$ dan disiplin kerja. Artinya apabila loyalitas, kemampuan kerja, kematangan pegawai dan disiplin kerja pegawai semakin baik akan diikuti baiknya kinerja pegawai. Perubahan ini merupakan peningkatan apabila bertanda positip dan penurunan atau pengurangan jika bertanda negatif. Hal ini menunjukkan bahwa ada pengaruh positip loyalitas, kemampuan kerja, kematangan pegawai dan disiplin kerja terhadap kinerja pegawai Artinya apabila loyalitas, kemampuan kerja, kematangan pegawai dan 
disiplin kerja ditingkatkan akan diikuti peningkatan kinerja pegawai. Penelitian ini menggunakan tingkat kepercayaan 95\% ( $\alpha=$ $0.05)$

Tabel 4

Koefisien Regresi Uji F ANOVA

\begin{tabular}{|ll|r|l|r|l|l|}
\hline Model & \multicolumn{2}{l|}{$\begin{array}{l}\text { Sum of } \\
\text { Squares }\end{array}$} & & Mean Square & F & Sig. \\
\hline \multirow{2}{*}{1} & Regression & 103.213 & 4 & 25.803 & 41.727 & $.000^{\mathrm{b}}$ \\
& Residual & 50.089 & 81 & .618 & & \\
& Total & 153.302 & 85 & & & \\
\hline
\end{tabular}

a. Dependent Variable: Kinerja pegawai

b. Predictors: (Constant), Disiplin kerja, Loyalitas, Kemampuan kerja, Kematangan pegawai

Berdasarkan tabel di atas diketahui nilai F- disebutkan bahwa secara bersama-sama hitung sebesar 41,727 sedangkan nilai F-tabel (multiple) terdapat pengaruh positif dan (terlampir) dengan $\mathrm{dk}$ pembilang $4 \mathrm{dan} \mathrm{dk}$ signifikan loyalitas, Kemampuan kerja, penyebut 81 adalah sebesar 2,48 dimana F- kematangan pegawai dan disiplin terhadap hitung > F tabel $(41,727>2,48)$ maka dapat kinerja pegawai

Tabel 5

Uji Determinasi $\left(\mathrm{R}^{2}\right)$

Model Summary

\begin{tabular}{|l|l|l|l|l|l|}
\hline Model & $\mathrm{R}$ & R Square & $\begin{array}{l}\text { Adjusted R R } \\
\text { Square }\end{array}$ & $\begin{array}{l}\text { Std. Error of } \\
\text { the Estimate }\end{array}$ & $\begin{array}{l}\text { Durbin- } \\
\text { Watson }\end{array}$ \\
\hline 1 & $.821^{\mathrm{a}}$ & .673 & .657 & .78637 & 1.985 \\
\hline
\end{tabular}

a. Predictors: (Constant), Disiplin kerja, Loyalitas, Kemampuan kerja, Kematangan pegawai

b. Dependent Variable: Kinerja pegawai

Berdasarkan tabel 5 diperoleh $\mathrm{R}^{2}=0,673$ maka $\mathrm{D}=0,673 \times 100 \%$ sehingga $\mathrm{D}=67,3 \%$. Dengan demikian pengaruh loyalitas, Kemampuan kerja, kematangan pegawai dan disiplin kerja terhadap Kinerja pegawai sebesar $67,3 \%$. sedangkan $32,7 \%$ lagi yang mempengaruhi Kinerja pegawai ditentukan faktor lain yang tidak diteliti dalam penelitian ini.

\section{Kesimpulan}

Berdasarkan hasil analisis data Loyalitas pegawai di Kantor Pelayanan Pajak Pratama Medan Timur umumnya kurang baik, Kemampuan kerja di Kantor Pelayanan Pajak Pratama Medan Timur cukup mampu, kematangan pegawai di Kantor Pelayanan Pajak Pratama Medan Timur kurang matang, disiplin kerja kurang disiplin Kinerja pegawai pegawai juga kurang tinggi. Kinerja pegawai pegawai dapat meningkat apabila Loyalitas semakin tinggi, Kemampuan kerja semakin baik kematangan pegawqai semakain matang dan disiplin kerjsa semakin disiplin karena hasil analisis regresi dan pengujian hipotesis diperoleh terdapat pengaruh signifikan loyalitas, kemampuan Kerja, kematangan pergawai dan disiplin secara bersama-sama terhadap Kinerja pegawai. Apabila loyalitas,, kemampuan kerja, kematangan pegawai dan disiplin kerja ditingkatkan $1 \%$ maka Kinerja pegawai akan naik $1 \%$. Besarnya pengaruh Loyalitas Pegawai, kemampuan kerja, kematangan pegawai dan disiplin kerja terhadap Kinerja pegawai dapat diketahui melalui uji determinasi

\section{DAFTAR PUSTAKA}

Ageng Prawatya (2015), Pengaruh Motivasi, Kemampuan dan disiplin kerja terhadap kinerja Karyawan Pada PT. PLN Cabang Weleri

Aldrianto Muhammad (2016), Pengaruh Disiplin dan Loyalitas Terhadap Kinerja Karyawan Pada PT. Kospermindo di Makasar

Ali, A.Y.S., Dahie, A.M., dan Ali, A.A. (2016). Teacher Motivation and School Performance, the Mediating Effect of Job Satisfaction: Survey from Secondary 
Schools in Mogadishu. International Journal of Education and Social Science Vol. 3 No. 1; January 2016

Amirullah, dan Hanafi, Rindyah. 2002. Pengantar Manajemen. Yogyakarta : Graha Ilmu.

Anoraga, Panji. 2010. Psiklogi Kerja. Jakarta : PT. Rineka Cipta.

Arikunto, Suharsimi. 2012. Prosedur Penelitian Suatu Pendekatan Praktek. Jakarta : Pt. Rhineka. Cipta.

Bafadal, Ibrahim. 2013. Peningkatan Profesionalisme Pegawai Instansi Dasar. Jakarta. PT. Rineka Cipta

Cross, T.M dan Lynch. R.R. (2012). Peniliaian dan Evaluasi Kinerja: Konsep dan Praktik. Jakarta. Penerbit Ghalia Indonesia

Danim, Sudarman. 2013. Agenda Pembaharuan Sistem Instansi. Jakarta : Pustaka Bekerja.

David, Fred, R. (2001). Manajemen Stratejik: Konsep dan Kasus. Edisi ke 9. Jakarta. Salemba Empat 